\title{
ANALISIS MOTIVASI MAHASISWA DALAM BELAJAR FISIKA
}

\author{
Petri Reni Sasmita ${ }^{1}$, Saiful Rachman ${ }^{2}$, Zainal Hartoyo ${ }^{3}$ \\ Program Studi Pendidikan Fisika STKIP Muhammadiyah Jambi ${ }^{1}$ \\ Program Studi Pendidikan Fisika Universitas Bengkulu ${ }^{2}$ \\ Program Studi Pendidikan Fisika Universitas Islam Negeri Sulthan Thaha Saifuddin Jambi ${ }^{3}$ \\ petrirenisasmita@gmail.com ${ }^{1}$
}

\section{Submit, 01-06-2018 Accepted,22-06-2018 Publish,22-06-2018}

\begin{abstract}
: the purpose of this study is to find out the comparative description of student motivation on the newly developed campus in physics learning with a more advanced campus. To get a description of the students' motivation, as many as 87 students selected at random from three different campuses were surveyed using Science Motivation Questionnaire II. The science motivation questionnaire consists of five components of motivation: intrinsic motivation, self-determination, self-efficacy, career motivation, and grade motivation. The results show that there is no significant difference between student motivation on the newly developed campus and student motivation on a more advanced campus in physics learning. If it is seen based on the motivation component, it is known that there is no significant difference between all components of student motivation on the newly developed campus with student motivation on campus which is more advanced.
\end{abstract}

Keyword: Physics Learning Motivation, Physics Learning, and Physics Education

\begin{abstract}
Abstrak: tujuan penelitian ini adalah untuk mengetahui deskripsi perbandingan motivasi mahasiswa pada kampus yang baru berkembang dalam belajar fisika dengan kampus yang sudah lebih maju. Untuk mendapatkan deskripsi motivasi mahasiswa tersebut, sebanyak 87 mahasiswa yang dipilih secara acak dari tiga kampus yang berbeda disurvei menggunakan Angket Motivasi Sains II. Angket motivasi sains tersebut terdiri dari lima komponen motivasi: motivasi intrinsik (intrinsic motivation), teguh pendirian (self-determination), percaya diri (self-efficacy), motivasi karir (career motivation), dan motivasi kelas (grade motivation). Hasilnya menunjukkan bahwa tidak terdapat perbedaan yang signifikan antara motivasi mahasiswa pada kampus yang baru berkembang dengan motivasi mahasiswa pada kampus yang lebih maju dalam belajar fisika. Jika dilihat berdasarkan komponen motivasi diketahui bahwa tidak terdapat perbedaan yang signifikan antara semua komponen motivasi mahasiswa pada kampus yang baru berkembang dengan motivasi mahasiswa pada kampus yang sudah lebih maju.
\end{abstract}

Katakunci: Motivasi Belajar Fisika, Pembelajaran Fisika, dan Pendidikan Fisika

\section{PENDAHULUAN}

Teori kognitif sosial yang dikembangkan oleh Bandura (2001) menyatakan bahwa karakteristik siswa, prilaku, dan lingkungan belajar harus dilihat secara interaktif dengan memperhatikan serangkaian interaksi timbal balik antara karakteristik pribadi, lingkungan belajar, dan perilaku.

Dalam teori kognitif sosial, pembelajaran yang paling efektif adalah ketika mahasiswa mengatur sendiri proses pembelajaran melalui memahami, memantau, mengendalikan motivasi dan prilaku mereka, yang menghasilkan hasil belajar yang mereka inginkan. Dalam teori ini, motivasi didefinisikan sebagai keadaan internal yang membangkitkan, mengarahkan, dan menopang prilaku yang berorientasi pada tujuan. Dengan definisi motivasi itu, maka motivasi belajar fisika dapat didefinisikan sebagai keadaan internal yang membangkitkan, mengarahakan, dan mendukung prilaku belajar fisika.

Druger (2006) berpendapat bahwa salah satu tujuan terpenting seorang pengajar fisika saat pertama kali masuk kelas adalah untuk membantu mahasiswa menjadi pembelajar mandiri yang 
termotivasi. Motivasinya dapat berupa motivasi intrinsik (intrinsic motivation), teguh pendirian (self-determination), kepercayaan diri (self-efficacy) (Glynn \& Koballa, 2006), dan motivasi ekstrinsik (extrinsic motivation): motivasi karir (career motivation), dan motivasi kelas (grade motivation) (Mazlo et.al., 2002).

Komponen motivasi ini berkontribusi positif terhadap gairah, arahan, dan ketahanan mahasiswa dalam belajar fisika. Dengan demikian, dapat dikatakan bahwa motivasi merupakan sesuatu yang sangat berperan dalam menjadikan mahasiswa sukses dalam belajar fisika.

Sekolah Tinggi Keguruan dan Ilmu Pendidikan Muhammadiyah Sangai Penuh (STKIP Muhammadiyah Sungai Penuh) merupakan kampus yang baru berkembang yang memerlukan banyak penelitian terkait dengan pembelajaran. Sebagai salah satu program studi yang ada di STKIP Muhammadiyah Sungai Penuh Program Studi Pendidikan Fisika juga sangat memerlukan penelitian terkait dengan pembelajaran khususnya pembelajaran fisika guna terciptanya lulusan yang berkompetensi.

Proses pembelajaran fisika tidak bisa dipisahkan dengan motivasi mahasiswa dalam belajar fisika. Hal ini bermakna bahwa motivasi mahasiswa dalam belajar fisika memiliki peranan yang penting dalam menentukan kesuksesan mahasiswa dalam proses pembelajaran.

Mengingat besarnya peran motivasi dalam kesuksesan mahasiswa dalam belajar fisika tersebut, maka kajian mengenai motivasi mahasiswa dalam belajar fisika merupakan sesuatu yang sangat penting dilakukan di STKIP Muhammadiyah Sungai Penuh. Tentu saja untuk mengkaji motivasi mahasiswa dalam belajar fisika di STKIP Muhammadiyah Sungai Penuh tidak bisa berdiri sendiri, sehingga membutuhkan data pembanding dari kampus-kampus lain seperti Universitas Islam Negeri
Sulthan Thaha Saifuddin Jambi (UIN STS Jambi), dan Universitas Islam Negeri Raden Fatah Palembang (UIN Raden Fatah Palembang).

Berdasarkan uraian di atas, penelitian ini difokuskan pada mengkaji motivasi mahasiswa program studi pendidikan fisika STKIP Muhammadiyah Sungai Penuh dalam belajar fisika. Kajian tersebut dilakukan dengan cara membandingkan data motivasi mahasiswa program studi fisika STKIP Muhammadiyah Sugai Penuh dengan mahasiswa program studi fisika UIN STS Jambi dan UIN Raden Fatah Palembang.

\section{LANDASAN TEORI}

Menurut Brophy (1988) motivasi belajar adalah kecenderungan siswa untuk melakukan kegiatan akademik yang berarti dan bermanfaat, serta mencoba mendapatkan manfaat akademis dari kegiatan akademik tersebut. Bentuk motivasi belajar yang penting bagi mahasiswa untuk belajar fisika meliputi: (1) motivasi ekstrinsik (extrinsic motivation) (Mazlo et.al., 2002), (2) motivasi intrinsik (intrinsic motivation), (3) teguh pendirian (self-determination), dan (4) percaya diri (self-efficacy) (Glynn \& Koballa, 2006).

Motivasi intrinsik (intrinsic motivation) adalah motivasi untuk melakukan sesuatu karena dirinya menyukainya atau menyenanginya (Ryan dan Deci, 2000). Mahasiswa yang termotivasi secara intrinsik akan merasa senang ketika mereka mampu menguasai suatu tugas dan berkonsentrasi penuh pada tugas yang sedang dihadapi. Misalnya, mahasiswa yang mengerjakan proyek-proyek sains akan menikmati prosesnya ketika proyek-proyek tersebut dikerjakan dengan cara yang berbedabeda.

Motivasi ekstrinsik (extrinsic motivation) adalah motivasi untuk melakukan sesuatu karena ada kaitannya dengan tujuan hidup (Ryan dan Deci, 2000). Misalnya, mahasiswa yang 
mengerjakan proyek-proyek sains akan termotivasi jika ada prospek proyek tersebut akan memperoleh penghargaan ketika proyek tersebut dilombakan pada suatu kompetisi. Motivasi ini dibagi lagi ke dalam dua komponen yang meliputi: motivasi karir (career motivation), dan motivasi kelas (grade motivation) (Mazlo et.al., 2002).

Teguh

pendirian

(self-

determination) merupakan kemampuan untuk memiliki pilihan dan memiliki tingkatan kontrol atas apa yang dilakukan dan bagaimana melakukkannya (Reeve dan Smith, 2003). Ketika mahasiswa diberi kesempatan untuk menentukan sendiri aktivitas pendidikan mereka, besar kemungkinannya mereka akan mendapatkan keuntungan dari hal tersebut dalam belajar.

Percaya diri (self-efficacy) adalah kepercayaan seseorang pada kemampuannya untuk mengatur dan melaksanakan tindakan yang diperlukan untuk menghasilkan suatu pencapaian (Bandura,1997). Kepercayaan seorang mahasiswa mengenai kemampuannya untuk sukses di bidang sains. Self-efficacy merupakan sesuatu yang spesifik karena seorang mahasiswa mungkin memiliki self-efficacy yang tinggi pada pengetahuan dan keterampilan dalam biologi, namun rendah self-efficacy-nya berkenaan pengetahuan dan keterampilan dalam fisika.

\section{METODE PENELITIAN}

Sampel penelitian ini adalah 87 orang mahasiswa Program Studi Pendidikan fisika dari tiga universitas di wilayah Sumatra Bagian Selatan (Sumbagsel): STKIP Muhammadiyah Sungai Penuh, UIN STS Jambi, dan UIN Raden Fatah Palembang. Sampel penelitian diambil secara acak dari mahasiswa pendidikan fisika ketiga kampus tersebut. Sampel penelitian tersebut terdiri dari $15 \quad(17,2 \%)$ orang mahasiswa STKIP Muhammadiyah Sungai Penuh, $35(40,2 \%)$ orang mahasiswa UIN STS Jambi dan 37 $(42,5 \%)$ orang mahasiswa UIN Raden Fatah Palembang yang berasal dari empat angkatan.

Data motivasi mahasiswa dikumpulkan menggunakan angket motivasi sains yang dikembangkan oleh Glynn \& Koballa (2006) dan disempurnakan oleh Glynn et.al (2011). Angket tersebut terdiri atas 25 item yang meliputi: (1) motivasi intrinsik (intrinsic motivation) lima item $(1,3,12,17,19)$, (2) teguh pendirian (self-determination) lima item $(5,6,11,16,22),(3)$ percaya diri $($ selfefficacy) lima item $(9,14,15,18,21)$, (4) motivasi karir (career motivation) lima item $(7,10,13,23,25)$, dan (5) motivasi kelas (grade motivation) lima item $(2,4,8,20,24)$ (Glynn et.al, 2011). Setiap item berupa pernyataan yang dapat direspon oleh mahasiswa dengan cara memberikan skor 5 untuk selalu (always), 4 untuk sering (usually), 3 untuk kadangkadang (sometimes), 2 untuk jarang (ralely), dan 1 untuk tidak pernah (never), skor-skor ini ditentukan berdasarkan skala Likert (Glynn, Taasoobshirazi, dan Brickman, 2009).

Data yang dikumpulkan melalui angket tersebut kemudian dianalisis menggunakan analisis deskriptif dan uji-t independent samples test. Skor maksimum angket motivasi fisika adalah 125 dan skor minimumnya adalah 25 , sehingga untuk menentukan kategori motivasi mahasiswa dilakukan analisis deskriptif dengan cara membuat rentang skornya yaitu skor 25-50 = tidak pernah s.d. jarang (never to rarely) termotivasi, 51-75 = jarang s.d. kadang-kadang (ralely to sometimes) termotivasi, 76-100 = kadang-kadang s.d. sering (sometimes to often) termotivasi, dan skor 101-125 = sering s.d. selalu (often to always) termotivasi (Glynn, Taasoobshirazi, dan Brickman, 2009). Untuk mengetahui perbedaan motivasi antara mahasiswa program studi fisika STKIP Muhammadiyah Sungai Penuh dengan UIN STS Jambi dan UIN Raden Fatah 
Palembang maka data dianalisis menggunakan uji-t independent samples test.

\section{HASIL PENELITIAN}

Motivasi mahasiswa dalam belajar fisika secara total termasuk dalam kategori kadang-kadang s.d. sering termotivasi. Motivasi mahasiswa STKIP Muhammadiyah Sungai Penuh secara rata-rata termasuk kedalam kategori sering s.d. selalu termotivasi, mahasiswa UIN STS Jambi secara rata-rata termasuk ke dalam kategori kadang-kadang s.d. sering termotivasi dan mahasiswa UIN Raden Fatah Palembang secara rata-rata termasuk ke dalam kategori kadangkadang s.d. sering termotivasi. Hasil analisis data mengenai kategori motivasi mahasiswa dalam belajar fisika ditunjukkan pada tabel 1 .

Tabel 1. Kategorisasi motivasi mahasiswa dalam belajar fisika

\begin{tabular}{|c|c|c|c|}
\hline Kampus & $\begin{array}{l}\text { Rata } \\
\text {-rata }\end{array}$ & $\begin{array}{l}\text { Simpang } \\
\text { an Baku }\end{array}$ & Kategori \\
\hline $\begin{array}{c}\text { STKIP } \\
\text { Muhammadi } \\
\text { yah }\end{array}$ & $\begin{array}{c}101,4 \\
1\end{array}$ & 20,77 & $\begin{array}{l}\text { sering s.d. } \\
\text { selalu }\end{array}$ \\
\hline $\begin{array}{c}\text { UIN STS } \\
\text { Jambi }\end{array}$ & 99,14 & 17,85 & $\begin{array}{l}\text { Kadang- } \\
\text { kadang s.d. } \\
\text { sering } \\
\text { termotivasi }\end{array}$ \\
\hline $\begin{array}{l}\text { UIN Raden } \\
\text { Fatah } \\
\text { Palembang }\end{array}$ & 92,4 & 23,17 & $\begin{array}{l}\text { Kadang- } \\
\text { kadang s.d. } \\
\text { sering } \\
\text { termotivasi }\end{array}$ \\
\hline Total & 97,65 & 20,8 & $\begin{array}{l}\text { Kadang- } \\
\text { kadang s.d. } \\
\text { sering } \\
\text { termotivasi }\end{array}$ \\
\hline
\end{tabular}

Perbedaan motivasi mahasiswa dalam belajar fisika antara mahasiswa STKIP Muhammadiyah Sungai Penuh dengan mahasiswa UIN STS Jambi dan antara mahasiswa STKIP Muhammadiyah Sungai Penuh dengan mahasiswa UIN Raden Fatah Palembang diketahui dengan cara melakukan analisis data motivasi mahasiswa menggunakan uji-t independent samples test. Berdasarkan uji tersebut diketahui bahwa secara umum tidak terdapat perbedaan yang signifikan antara motivasi mahasiswa STKIP Muhammadiyah Sungai Penuh dengan mahasiswa UIN STS Jambi dan antara mahasiswa STKIP Muhammadiyah Sungai Penuh dengan mahasiswa UIN Raden Fatah Palembang. Hasil analisis data motivasi mahasiswa pendidikan fisika secara umum selengkapnya ditunjukkan pada Tabel 2.

Tabel 2. Rekapitulasi hasil analisis data motivasi mahasiswa STKIP Muhammadiyah Sungai Penuh dibandingkan dengan kampus lain

\begin{tabular}{ccc}
\hline Jenis Kelamin & Sig. (2-tailed) & $\boldsymbol{\alpha}$ \\
\hline $\begin{array}{c}\text { STKIP } \\
\text { Muhammadiyah }\end{array}$ & 0,81 & 0,05 \\
\hline UIN STS Jambi & & \\
\hline $\begin{array}{c}\text { STKIP } \\
\text { Muhammadiyah }\end{array}$ & 0,24 & 0,05 \\
\hline $\begin{array}{c}\text { UIN Raden Fatah } \\
\text { Palembang }\end{array}$ & & \\
\hline
\end{tabular}

Berdasarkan tabel 2, dapat diketahu bahwa skor sig.2-tailed-nya tidak ada yang lebih kecil dari skor $\alpha=0,05$. Hal ini berarti bahwa tidak terdapat perbedaan yang signifikan antara data motivasi mahasiswa STKIP Muhammadiyah Sungai Penuh dengan data motivasi UIN STS Jambi dan antara data motivasi STKIP Muhammadiyah Sungai Penuh dengan UIN Raden Fatah Palembang.

Selain dianalisis secara umum, motivasi mahasiswa fisika juga dianalisis per komponennya menggunakan uji-t independent samples test. Berdasarkan analisis tersebut diketahui bahwa secara motivasi intrinsik (intrinsic motivation), teguh pendirian (self-determination), percaya diri (self-efficacy), motivasi karir (career motivation), dan motivasi kelas (grade motivation) tidak terdapat perbedaan yang signifikan anatara mahasiswa STKIP Muhammadiyah Sungai Penuh dengan mahasiswa UIN STS Jambi dan antara mahasiswa STKIP Muhammadiyah Sungai Penuh dengan mahasiswa UIN Raden Fatah Palembang, 
namun secara rata-rata mahasiswa STKIP Muhammadiyah Sungai Penuh lebih termotivasi dalam setiap komponen motivasi dibandingkan dengan mahasiswa UIN STS Jambi dan UIN Raden Fatah Palembang. Hasil analisis data motivasi mahasiswa dalam belajar fisika berdasarkan komponen motivasinya selengkapnya ditunjukkan pada tabel 3 dan tabel 4.

Tabel 3. Rekapitulasi hasil analisis data komponen motivasi antara STKIP Muhammadiyah Sungai Penuh dengan mahasiswa UIN STS Jambi

\begin{tabular}{|c|c|c|c|c|c|}
\hline $\begin{array}{c}\text { Bentuk } \\
\text { motivasi }\end{array}$ & Kampus & $\begin{array}{c}\text { Rata- } \\
\text { rata }\end{array}$ & $\begin{array}{c}\text { Simpangan } \\
\text { Baku }\end{array}$ & $\begin{array}{l}\text { Sig. (2- } \\
\text { tailed) }\end{array}$ & $\alpha$ \\
\hline \multirow{4}{*}{$\begin{array}{l}\text { Intrinsic } \\
\text { motivation }\end{array}$} & STKIP & & & \multirow{4}{*}{0,95} & \multirow{4}{*}{0,05} \\
\hline & Muhammadiy & 20,46 & 5,08 & & \\
\hline & UIN STS & & & & \\
\hline & Jambi & 20,54 & 3,96 & & \\
\hline \multirow{4}{*}{$\begin{array}{l}\text { Self- } \\
\text { determinati } \\
\text { on }\end{array}$} & STKIP & & & \multirow{4}{*}{0,33} & \multirow{4}{*}{0,05} \\
\hline & Muhammadiy & 19,73 & 4,45 & & \\
\hline & $\mathrm{ah}$ & & & & \\
\hline & $\begin{array}{l}\text { UIN STS } \\
\text { Jambi }\end{array}$ & 19,40 & 3,76 & & \\
\hline \multirow{3}{*}{$\begin{array}{l}\text { Self- } \\
\text { efficacy }\end{array}$} & STKIP & & & \multirow{3}{*}{0,87} & \multirow{3}{*}{0,05} \\
\hline & $\begin{array}{l}\text { Muhammadiy } \\
\text { ah }\end{array}$ & 19,06 & 4,57 & & \\
\hline & $\begin{array}{l}\text { UIN STS } \\
\text { Jambi }\end{array}$ & 18,88 & 3,49 & & \\
\hline \multirow{3}{*}{$\begin{array}{l}\text { Career } \\
\text { motivation }\end{array}$} & STKIP & & & \multirow{3}{*}{0,58} & \multirow{3}{*}{0,05} \\
\hline & $\begin{array}{l}\text { Muhammadiy } \\
\text { ah }\end{array}$ & 20,53 & 4,59 & & \\
\hline & $\begin{array}{l}\text { UIN STS } \\
\text { Jambi }\end{array}$ & 19,77 & 4,39 & & \\
\hline \multirow{3}{*}{$\begin{array}{l}\text { Grade } \\
\text { motivation }\end{array}$} & STKIP & & & \multirow{3}{*}{0,62} & \multirow{3}{*}{0,05} \\
\hline & $\begin{array}{l}\text { Muhammadiy } \\
\text { ah }\end{array}$ & 21,20 & 4,66 & & \\
\hline & $\begin{array}{l}\text { UIN STS } \\
\text { Jambi }\end{array}$ & 20,54 & 4,13 & & \\
\hline
\end{tabular}

Berdasarkan Tabel 3, dapat diketahui bahwa rata-rata semua komponen motivasi berada pada rentang 18 s.d 21 yang bermakna motivasi mahasiswa setiap komponennya berada pada kategori sering termotivasi. Selanjutnya, pada Tabel 3 juga dapat diketahui bahwa tidak ada skor sig.2tailed yang lebih kecil dari skor $\alpha$, hal ini berarti tidak ada perbedaan yang signifikan pada setiap komponen motivasi mahasiswa STKIP Muhammadiyah Sungai Penuh dengan mahasiswa UIN STS Jambi.
Tabel 4. Rekapitulasi hasil analisis data komponen motivasi antara STKIP Muhammadiyah Sungai Penuh dengan mahasiswa UIN Raden Fatah Palembang

\begin{tabular}{|c|c|c|c|c|c|}
\hline $\begin{array}{c}\text { Bentuk } \\
\text { motivasi }\end{array}$ & Kampus & $\begin{array}{c}\text { Rata- } \\
\text { rata }\end{array}$ & $\begin{array}{c}\text { Simpangan } \\
\text { Baku }\end{array}$ & $\begin{array}{l}\text { Sig. (2- } \\
\text { tailed) }\end{array}$ & $\alpha$ \\
\hline \multirow{2}{*}{$\begin{array}{l}\text { Intrinsic } \\
\text { motivation }\end{array}$} & $\begin{array}{l}\text { STKIP } \\
\text { Muhammad } \\
\text { iyah }\end{array}$ & 20,46 & 5,08 & \multirow{2}{*}{0,14} & \multirow{2}{*}{0,05} \\
\hline & $\begin{array}{l}\text { UIN Raden } \\
\text { Fatah } \\
\text { Palembang }\end{array}$ & 18,00 & 5.52 & & \\
\hline \multirow{2}{*}{$\begin{array}{l}\text { Self- } \\
\text { determinati } \\
\text { on }\end{array}$} & $\begin{array}{l}\text { STKIP } \\
\text { Muhammad } \\
\text { iyah }\end{array}$ & 19,73 & 4,45 & \multirow{2}{*}{0,31} & \multirow{2}{*}{0,05} \\
\hline & $\begin{array}{l}\text { UIN Raden } \\
\text { Fatah } \\
\text { Palembang }\end{array}$ & 18,26 & 4,69 & & \\
\hline \multirow{2}{*}{$\begin{array}{l}\text { Self- } \\
\text { efficacy }\end{array}$} & $\begin{array}{l}\text { STKIP } \\
\text { Muhammad } \\
\text { iyah }\end{array}$ & 19,06 & 4,57 & \multirow{2}{*}{0,56} & \multirow{2}{*}{0,05} \\
\hline & $\begin{array}{l}\text { UIN Raden } \\
\text { Fatah } \\
\text { Palembang }\end{array}$ & 18,20 & 4,87 & & \\
\hline \multirow{2}{*}{$\begin{array}{l}\text { Career } \\
\text { motivation }\end{array}$} & $\begin{array}{l}\text { STKIP } \\
\text { Muhammad } \\
\text { iyah }\end{array}$ & 20,53 & 4,59 & \multirow{2}{*}{0,16} & \multirow{2}{*}{0,05} \\
\hline & $\begin{array}{l}\text { UIN Raden } \\
\text { Fatah } \\
\text { Palembang }\end{array}$ & 18,37 & 5,03 & & \\
\hline \multirow{2}{*}{$\begin{array}{l}\text { Grade } \\
\text { motivation }\end{array}$} & $\begin{array}{l}\text { STKIP } \\
\text { Muhammad } \\
\text { iyah }\end{array}$ & 21,20 & 4,66 & \multirow{2}{*}{0,13} & \multirow{2}{*}{0,05} \\
\hline & $\begin{array}{l}\text { UIN Raden } \\
\text { Fatah } \\
\text { Palembang }\end{array}$ & 18,82 & 5,09 & & \\
\hline
\end{tabular}

Berdasarkan Tabel 4, dapat diketahui bahwa rata-rata semua komponen motivasi berada pada rentang 18 s.d 21 yang bermakna motivasi mahasiswa setiap komponennya berada pada kategori sering termotivasi. Selanjutnya, pada Tabel 4 juga dapat diketahui bahwa tidak ada skor sig.2tailed yang lebih kecil dari skor $\alpha$, hal ini berarti tidak ada perbedaan yang signifikan pada setiap komponen motivasi mahasiswa STKIP Muhammadiyah Sungai Penuh dengan mahasiswa UIN Raden Fatah Palembang.

\section{PEMBAHASAN}

Hasil penelitian ini menunjukkan bahwa secara keseluruhan motivasi mahasiswa dalam belajar fisika berada pada kategori kadang-kadang s.d. sering termotivasi. Temuan ini sejalan dengan hasil penelitian Hartoyo (2018) yang menemukan bahwa rata-rata motivasi 
mahasiswa fisika dalam belajar fisika berada pada kategori kadang-kadang s.d. sering termotivasi. Dengan diketahuinya kategori motivasi mahasiswa ini, maka sudah seharusnya pembelajaran fisika yang diterapkan merupakan pembelajaran yang dapat lebih memotivasi mahasiswa sehingga dalam belajar fisika mahasiswa akan selalu termotivasi. Pembelajaran itu dapat berupa pembelajaran fisika berbasis konteks yang memungkinkan mahasiswa untuk lebih aktif terlibat mengkonstruksi pengetahuan dalam proses pembelajaran (Taasoobshirazi, 2007). Pembelajaran fisika berbasis konteks merupakan pembelajaran yang menghubungkan proses belajar dengan dunia nyata yang memungkinkan mahasiswa menerapkan apa yang mereka pelajari pada kegiatan kehidupan mereka sehari-hari.

Motivasi mahasiswa STKIP Muhammadiyah Sungai Penuh dalam belajar tidak berbeda secara signifikan dengan motivasi mahasiswa UIN STS Jambi dan UIN Raden Fatah Palembang. Hal ini menandakan bahwa dalam hal memotivasi mahasiswa dalam belajar fisika STKIP Muhammadiyah Sungai Penuh tidak tertinggal dari universitas lain yang sudah lebih maju seperti UIN STS Jambi dan UIN Raden Fatah Palembang. Namun, jika dilihat berdasarkan komponen motivasi ada hal yang menarik dimana ternyata rata-rata skor motivasi mahasiswa STKIP Muhammadiyah Sungai Penuh paling rendah terletak pada komponen percaya diri (self-efficacy). Ini artinya, mahasiswa STKIP Muhammadiyah Sungai Penuh rasa percaya dirinya perlu ditingkatkan. Untuk meningkatkan rasa percaya diri mahasiswa dalam belajar fisika maka pembelajaran yang dilakukan dapat berupa memberi kebebasan kepada mahasiswa dalam menentukan pilihan cara mengerjakan tugas dan proyek (Kaschalk, 2002).

Jika dilihat setiap komponen motivasi, rata-rata komponen motivasi paling rendah adalah motivasi intrinsik mahasiswa UIN Raden Fatah Palembang. Motivasi intrinsik timbul karena rasa suka atau senang (Ryan dan Deci, 2000). Untuk memacu motivasi ini dalam diri mahasiswa maka yang dapat dilakukan adalah menerapkan penugasan dan pembelajaran dengan menggunakan metode yang berbeda-beda (Glynn \& Koballa, 2006). Olehkarena itu, pembelajaran fisika dikumpus harus menggunakan metode yang tidak monoton, atau menggunakan metode yang sama dari awal perkuliahan sampai akhir perkuliahan.

Suatu hal yang paling menarik dari hasil penelitian ini adalah secara rata-rata setiap komponen motivasi mahasiswa UIN Raden Fatah Palembang ternyata lebih rendah dari STKIP Muhammadiyah Sungai Penuh. Hal ini mengindikasikan bahwa kampus yang sudah maju bukan jaminan motivasi mahasiswanya juga dalam kategori yang bagus. Oleh karena itu, kampus-kampus perlu mengedepankan pembelajaran yang dapat memotivasi mahasiswa dalam belajar khususnya dalam belajar fisika. Pembelajaran yang dapat memotivasi tersebut dapat berupa pembelajaran aktif dan pembelajaran berbasis konteks atau kontekstual (Wilkinson, 1999).

\section{SIMPULAN}

Penelitian ini bertujuan untuk mengetahui gambaran motivasi mahasiswa STKIP Muhammadiyah Sungai Penuh dalam belajar fisika dan membandingkan motivasi mahasiswa tersebut dengan kampus lain yang sudah lebih maju. Hasilnya menunjukkan bahwa (1) motivasi mahasiswa STKIP Muhammadiyah Sungai Penuh dalam belajar fisika berada pada kategori sering s.d. selalu termotivasi, (2) jika dibandingkan dengan kampus lain yang sudah lebih maju, secara umum motivasi mahasiswa STKIP Muhammadiyah Sungai Penuh tidak berbeda secara signifikan dengan kampus lain yang sudah lebih maju, dan (3) jika dilihat dari 
komponen motivasinya, semua komponen motivasi mahasiswa STKIP Muhammadiyah Sungai Penuh tidak berbeda secara signifikan dengan motivasi mahasiswa kampus lain yang sudah lebih maju.

\section{DAFTAR PUSTAKA}

Bandura, A. (2001). Social cognitive theory: An agentive perspective. Annual Review Psychology, 52, 126

Druger, M. (2006). Experiential Learning in a large introductory biology course. In J. Mintzes \& W. H. Leonard (Eds.), Handbook of college Science Teaching. Arlington, VA: National Science Teacher Association Press.

Glynn, S.M., \& Koballa, T.R. (2006). Motivation to Learn College Science. In J. Mintzes \& W. H. Leonard (Eds.), Handbook of college Science Teaching. Arlington, VA: National Science Teacher Association Press.

Brophy, J. E. (1988). On Motivation Students. Dalam Talks to Teacher, Editor D. Berliner dan B. Rosenshine, 201-245. New York: Random House.

Mazlo, J., Dormedy, D. F., NeimothAnderson, J. D., Urlacher, T., Carson, G. A., \& Kelter, P. B. (2002). Assessment of motivation methods in general chemistry laboratory. Journal of College Science Teaching, 36, 318-321.

Glynn, S. M., Brickman, P., Armstrong, N., \& Taasoobshirazi, G. (2011). Science Motivation Questionnaire II: Validation With Science Majors and Nonscience Majors, Journalof Research in Science Teaching, 48(10),1159-1176

Ryan, R. M., \& Deci, E. L. (2000). Intrinsicand Extrinsic Motivations: Classic Definitions and New Directions, Contemporary Educational Psychology, 25, 54-67
Reeve, P. R., Smith, D. A. F., \& Nix,G. (2003). Testing Models of The Experience of self-determination in intrinsic motivation and the conundrum of choice, Journal of Educational Psychology, 95, 375392

Bandura, A. (1997). Self-efficacy: The exerciseof control. New York: Freeman.

Glynn, S.M., Taasoobshirazi, G., \& Brickman, P. (2009). Science Motivation Questionnaire: Construct Validation With Nonscience Majors, Journalof Research in Science Teaching, 48 (2), 127-146

Hartoyo, Z. (2018). Tak tau Motivasi Tak Mau Belajar Fisika. Journal of Mathematic, Science, and Technology, 1, 1-7.

Taasoobshirazi, G. (2007). Gender differences in Physics: A Focus on Motivation. Journal of Physics Teacher Education Online, 4(3), 712

Kaschalk, R. (2002). Physics-why bother?...that's why! Contextual Teaching Exchange, 1,1-8

Wilkinson, J. (1999). Teachers' perceptions of the contextual approach to teaching VCE physics. Australian Science Teachers Journal, 45, 58-65 